\title{
Pollen Viability and Autogamy Fitness in Bauhinia forficata Link (Fabaceae)
}

\author{
Luana Camila Capitani ${ }^{1}$, Ana Paula Moreira Rovedder ${ }^{1}$, \\ José Carlos Corrêa da Silva Júnior ${ }^{1}$, Aline Peccatti ${ }^{1}$
}

${ }^{1}$ Universidade Federal de Santa Maria - UFSM, Santa Maria/RS, Brasil

\begin{abstract}
Bauhinia forficata (Fabaceae) occurs in many phytophysiognomies of southern Brazil, however its ecological relevance is not well understood. The present study was developed in the Central Depression of Rio Grande do Sul and aimed to determine variations in pollen viability along flowering, ability to perform autogamy and dye efficiency for the viability test. Pollen viability was determined by colorimetry as well as the ability to perform autogamy by isolating floral buds, being evaluated in eleven matrices. Average pollen viability was $81.43 \%$, with the highest average value obtained with the dye 2,3,5- Triphenyltetrazolium Chloride (TTC) (84.11\%). Safranin was not a good indicator at the tested concentration. No correlation was found between pollen viability and flowering time. The species demonstrated an inability to perform autogamy.
\end{abstract}

Keywords: colorimetric method, pollen, TTC. 


\section{INTRODUCTION}

Pollen is primarily the transport vehicle of the male gamete, in addition to being the most important source of proteins for floral visitors and pollinators (Agostini et al., 2014; Westerkamp, 2004). Its composition is mainly protein, however it also contains sugars, lipids, and phosphorus among other substances important for the survival of floral visitors (Willmer, 2011). In addition to the reproductive function of pollen, it is likely that it was evolutionarily the first floral resource to be used by animals as a source of food (Lunau, 2006).

Pollen quality expressed by viability is extremely important for the sexual reproductive success of plant species, since they cannot directly choose their reproductive partners (Oliveira \& Maruyama, 2014), and the greater the viability, longevity and pollen germination, the greater the genetic variability of a species will be (Akoroda, 1983).

Maintaining genetic diversity is essential for the evolution of a species to occur and to reduce the chances of extinction in the ecosystem, even in the face of natural or induced changes. Therefore, the adoption of diversity maintenance strategies in conservation plans is essential (Zanella et al., 2012; Frankham, 2010). However, the reproductive success of plant species not only depends on pollen viability rates, but also on the efficiency in the pollen transfer to the feminine part of the flower, preferably belonging to an individual with genetic characteristics different from the plant that originated the male gamete.

Therefore, it is worth highlighting that autogamy can lead to a loss of genetic variability, making the species more susceptible to environmental changes and, sometimes resulting in the local extinction of a species. In this way, many plants developed mechanisms over time to prevent self-pollination from occurring, including the adoption of strategies to induce genic flow, as the offer of resources (Rech et al., 2014).

Among the species of Deciduous Seasonal Forest in Rio Grande do Sul, Bauhinia forficata stands out because it presents easy adaptation to different climates and regions. It can be found in diverse phytophysiognomies such as the Mixed Ombrophilous Forest, both in Montaineous as well as Sub-Montaineous, Semideciduous Mesophyll Forest, Ciliary and Riparian Forest, Secondary Semideciduous and Seasonal Semideciduous Forest, and Deciduous Forest (Pezzopane et al., 2003; Marangon et al., 2008; Longhi et al., 2005; Valério et al., 2008; Avila et al., 2011; Moraes \& Almeida, 2009).

The species also presents medicinal potential (Engel et al., 2008; Silva \& Cechinel, 2002; Marques et al., 2013), being frequently used in folk medicine and pharmacognosy. In addition to standing out due to the quantity and quality of the floral resources offered, it also contributes by attracting and maintaining the nectarivorous and pollinating fauna (Paulino, 2013), therefore acting as a key species in the maintenance of ecological interactions in ecosystems associated with it. For these reasons, it is also indicated for the restoration of degraded areas.

Therefore, the present study aimed to determine the pollen viability of Bauhinia forficata through colorimetric analysis as well the efficacy of Basic Fuchsin (1\%), Safranin (1\%), Methyl Red (1\%) and 2, 3, 5 - Triphenyltetrazolium Chloride (TTC) (1\%) dyes for determining the pollen viability of the species, and to test its ability to perform autogamy through isolating the action of pollen biotic vectors.

\section{MATERIAL AND METHODS}

The study area is located in the district of Arroio Grande, part of the Santa Maria municipality - RS $\left(29^{\circ} 41^{\prime} 25^{\prime \prime} \mathrm{S}, 5^{\circ} 48^{\prime} 42^{\prime \prime} \mathrm{W}\right)$. The region is located in the Atlantic Forest Biome, with a predominantly subtropical humid climate (ST UM) (Maluf, 2000) and a Deciduous Seasonal Forest of subtropical climate.

Identification of the species was performed by the Herbarium of the Forestry Sciences Department- Santa Maria Federal University (HDCF). The choice of Bauhinia forficata matrices was based on phenotypic characteristics associated with the viability of the collection and experimental execution such as the size and accessibility of the treetop, characteristics of physiological vigor such as health and the appearance of the treetop and leaves, absence of symptoms of nutritional scarcity in leaves and branches, the presence, quantity and maturation of flower buds and flowers, and on the analysis of the individuals' phytosanitation, according to the visual classification proposed by Nicodemo et al. (2009). 
Only those individuals that presented the best combination of the phenotypic and physiological vigor factors, and that were included in Grade 1 (Light: less than $25 \%$ of the damaged plant) in the phytosanitary analysis were selected as matrices. Additionally, given that the species presents the ability to sprout from the roots, individuals at least $50 \mathrm{~m}$ apart from one another were characterized as distinct matrices, or at a lower distance when the existence of distinct individuals could be verified.

Flower collection was performed in 11 matrices during January 2015, in seven non-consecutive evaluations. Anthers samples of three flowers per evaluation day were collected and stored in solution (Ethanol - Acetic acid (3: 1)) for each matrix, and maintained in a refrigerated environment $\left(\approx-18^{\circ} \mathrm{C}\right)$ until the time of evaluation (9 months after collection).

Pollen viability was determined by colorimetric methods with the aid of Basic Fuchsin (1\% solution) dye, which reacts with pollen protoplasm blushing pink; Safranin dye (1\%), related to cell wall integrity and also blushing pink; Red Methyl dye (1\%), which reacts with the viable pollen by blushing an intense red; and finally 2,3,5-Triphenyltetrazolium Chloride (TTC-1\%), which indicates the presence of active dehydrogenases enzymes involved in the process of cellular respiration, turning the pollen a reddish-pink (Santos et al., 2006; Munhoz et al., 2008).

The anthers were macerated and the pollen transferred to microscopy slides containing one drop of dye and semi-permanent blades were subsequently assembled, of which the total number of pollen grains and the number of viable pollen grains per sample was determined (adapted of Munhoz et al., 2008 and Vida et al., 2011). Larger pollen grains with more intense staining were considered viable. Pollen viability was calculated by the following Formula 1 (Santos et al., 2006):

Viability $(\%)=\frac{\text { number of stained pollen grains }}{\text { total number of pollen grains }} \times 100$

For the autogamy aptitude test (with the purpose of preventing the interaction of pollen biotic vectors with the flower), three floral buds were isolated per matrix with the aid of Voil bags, totaling 33 floral buds, which were thus protected until the fruit ripening period (adapted from Aguiar \& Gaglianone, 2008 and
Mendes et al., 2011). This test determined whether anthesis of the isolated buds and the formation of fruit occurred or not.

A comparison of significant differences between pollen viability averages was carried out with the aid of Software Assistat (Santos-e-Silva, 2015), through the Kruskal-Wallis test (Cargnelutti et al., 2001). The correlation between pollen viability and flowering time was tested by regression analysis, and the significance of correlations was determined through the estimation of the " $\mathrm{t}$ " statistic, comparing to Student's $\mathrm{t}$-values for n-2 DF and a significance level of 5\%.

\section{RESULTS AND DISCUSSION}

Bauhinia forficata pollen presented structures named pollenkitt, which serve to aid in adhesion of the pollen to the floral visitors, as well allowing for the identification of the species, since the conformation of pollenkitt is unique for each species (Lin et al., 2013) (Figure 1).

Average pollen viability was $81.43 \%$. Regarding the dyes, the highest viability average was obtained using the TTC dye (84.11\%) (Figure 2). The average viability obtained with the Basic Fuchsin dye was 81.77\% (Figure 3), and with the Methyl Red dye it was $78.4 \%$ (Figure 4), all considered high according to Souza et al. (2002). Germinated pollen grains could also be observed throughout the evaluations, presenting a mean germination percentage of $5.52 \%$ (Figure $3 \mathrm{~A}$ ).

In studying the pollen of two species of the genus Tabebuia, Arenas-de-Souza et al. (2014) found an average viability value of approximately $75 \%$. Nascimento et al. (2014) found pollen viability from $56.60-81.10 \%$, for Delonix regia and Hister \& Tedesco (2016) found an average viability of $80.3 \%$ when studying Psidium cattleianum; values similar to those obtained in this research.

Safranin dye was not a good indicator of Bauhinia forficata pollen viability. The reaction intensity was low in all analyses, showing weak pollen coloration, which made it difficult to differentiate between viable and unviable pollen. On the other hand, Santos et al. (2006) and Bolat \& Pirlak (1999) obtained satisfactory results using Safranin for other plant species, even if they did not indicate it as the most effective dye. 


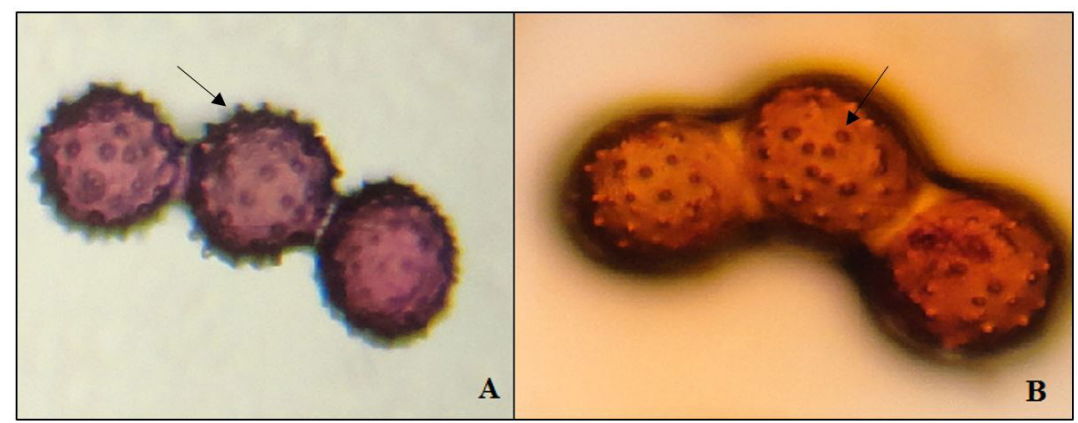

Figure 1. Viable pollen grains stained with Basic Fuchsin (1\%) (A) highlight the structure of pollenkitt - and pollen grains stained with Methyl Red; (B) highlight the structure of pollenkitt.

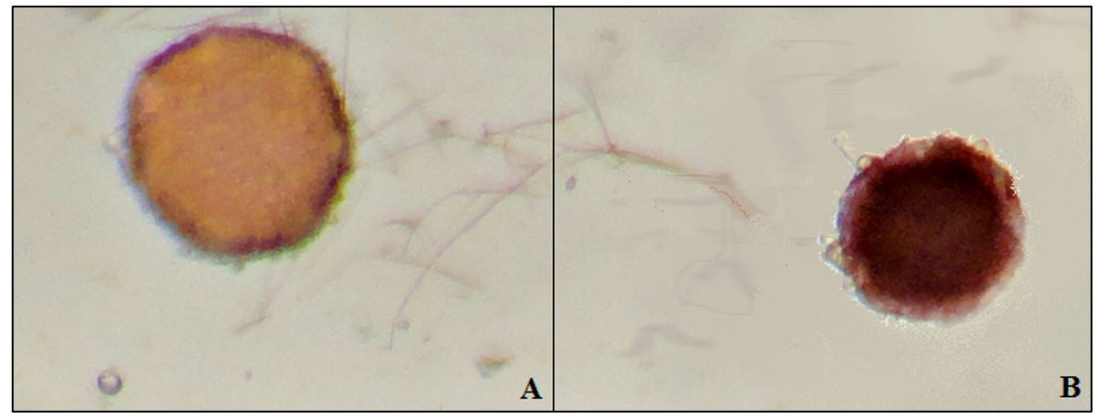

Figure 2. Bauhinia forficata pollen grain stained with 2,3,5- Triphenyltetrazolium Chloride (TTC): viable pollen (A) and unviable pollen (B).

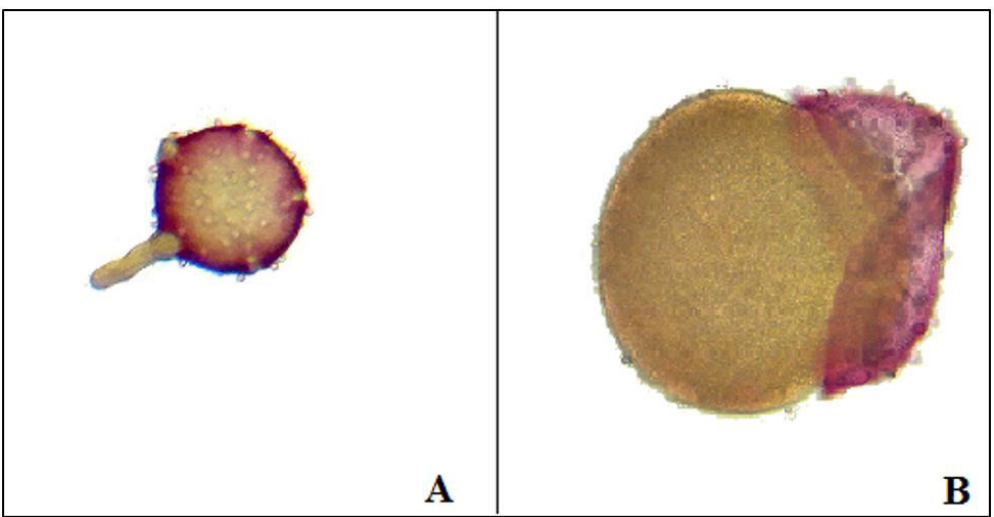

Figure 3. Bauhinia forficata pollen grain stained with Basic Fuchsin (1\%): germinated Pollen (A); ruptured cell wall (B).

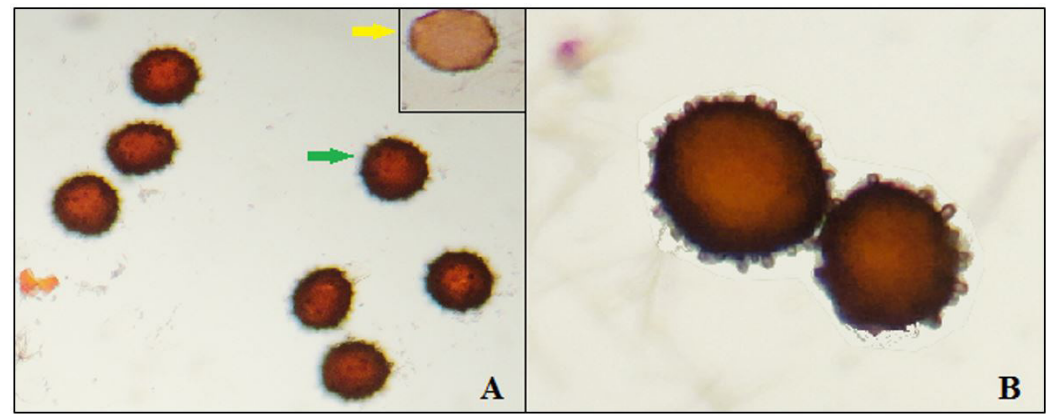

Figure 4. Bauhinia forficata pollen grains stained with Methyl Red (A) (green arrow highlighting viable pollen grain and yellow arrow highlighting unviable pollen grain); Highlighted for the pollenkitt structure (B). 
A significant difference in pollen viability between the matrices was observed through applying the Kruskal-Wallis test $(\mathrm{p}=0.05)$ (Table 1$)$; however, the origin of this variation is difficult to determine, since genetic, biotic and/or abiotic factors may be associated.

No correlation ( $\mathrm{r}_{\text {pearson }}=0.3001$ ), or causal relationship $\left(r^{2}{ }_{\text {adjus }}=0.05\right)$ was found between pollen viability and flowering time (Figure 5). In addition to genetic factors of the species, high viability rates may have been obtained due to the form of storage (in a solution with a storage temperature of approximately $-18^{\circ} \mathrm{C}$ ), since there are reports of reduced pollen viability from desiccation processes and maintenance of viability with storage at low temperatures (Pio et al., 2007).

The time and form of storage can significantly reduce pollen viability. For example, in analyzing the storage and pollen viability of Citrus cultivars for 9 weeks, Pio et al. (2007) found that pollen grain viability diminished with increased storage time. However, the data obtained for Bauhinia forficata show that the pollen of the species remains viable even after long storage periods ( 9 months in this case) and that the viability rate is high for all matrices, even throughout the flowering period.

There was a significant difference (Kruskal-Wallis, $\mathrm{p}=0.05$ ) between the basic Fuchsina and Methyl Red dyes; however, they did not differ statistically from the TTC dye, which even presented the highest viability rates amongst the results. Therefore, it is not possible to state that some of the dyes used overestimated the pollen viability of the species. Nevertheless, many authors cite the tendency of colorimetric tests to overestimate

Table 1. Pollen viability in Bauhinia forficata in the central region of Rio Grande do Sul.

\begin{tabular}{cccc}
\hline MATRIX & POLLEN VIABILITY (\%) & STATISTICAL RANKING \\
M1 & 81.14 & abc \\
M2 & 83.26 & abc \\
M3 & 71.42 & bc \\
M4 & 87.76 & $\mathrm{a}$ \\
M5 & 86.94 & $\mathrm{abc}$ \\
M6 & 82.98 & $\mathrm{abc}$ \\
M7 & 83.77 & $\mathrm{abc}$ \\
M8 & 83.48 & $\mathrm{abc}$ \\
M9 & 87.63 & $\mathrm{ab}$ \\
M10 & 78.68 & $\mathrm{abc}$ \\
\hline
\end{tabular}

*Values followed by the same letter do not differ statistically from one another by the application of Kruskal-Wallis test, at $5 \%$ level of significance.

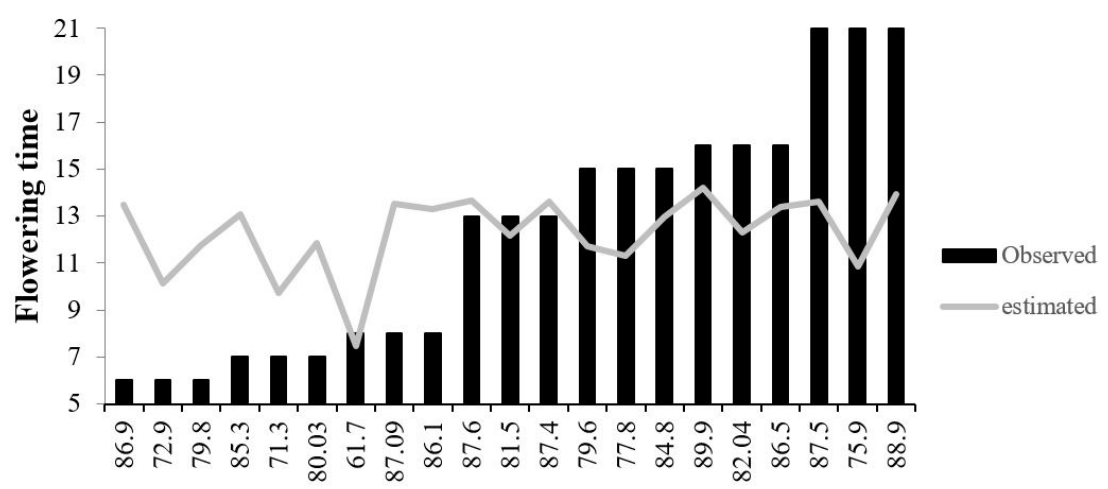

Pollinic viability

Figure 5. Correlation (cause and effect) between pollen viability and flowering time in Bauhinia forficata, demonstrating the viability observed throughout flowering (bars) and the viability expected by regression analysis (row) $\left(\mathrm{r}_{\text {ajus }}^{2}=0.05\right)$. 
the pollen viability of the species, suggesting that they be combined with other determination methods such as in vitro germination tests, tests of percentage and meiotic stability, amongst others, aiming to eliminate the intrinsic limitations of each method chosen (Munhoz et al., 2008; Arenas-de-Souza et al., 2014; Nascimento et al., 2014; Davide et al., 2009).

It should also be noted that the TTC dye, among those used in this study, is the only one that presented positive staining for metabolic activities of the pollen grains (active dehydrogenases enzymes) and not only for the constituent's integrity.

None of the floral buds isolated from the action of biotic vectors presented fruit formation, having flowered at the same time and with the same duration as the other floral buds of the treetop, demonstrating the inability of the species to perform autogamy. This characteristic is preferable in plant species because it decreases the chances of genetic drift and consequently local extinction risks (Rech et al., 2014). However, autogamy, apomixis, vegetative or asexual reproduction may be advantageous in species adapted to extreme environmental conditions or in species colonizing new areas. Even in these cases, where the degree of inbreeding is also high, events such as crossing over or somatic changes occur at random, thus ensuring both the genetic stability of the population and consequent local perpetuation as a degree of genetic variability that allows reproductive flexibility (Rech et al., 2014).

The extreme behavior in the induction of genic flow in reproductive systems would in theory be dioecius, where the pollination process always results in genic flow, since inbreeding is virtually impossible (Oliveira \& Maruyama, 2014). Nevertheless, any type of separation of sexual functions in plants, whether functional, structural, temporal, etc., would result in greater genic flow in the population and could characterize adaptive advantages in the species (Oliveira \& Maruyama, 2014).

Despite all this evidence, hermaphrodite flowers such as Bauhinia forficata are common in the plant kingdom and characteristic of most angiosperms on the planet. Studies related to the evolution of floral systems indicate that unlike in the most common hypothesis where the existence of hermaphrodite flowers results in higher self-pollination rates, hermaphroditism in plant species emerged as a strategy to increase gene flow (Allen \& Hiscock, 2008).
The Allen \& Hiscock (2008) statement can be evidenced in this experiment, because the impediment of pollen biotic vectors through isolation with Voil bags does not preclude the wind transporting pollen grains from nearby flowers in the same individual to the stigma of the flower (a process denominated geitonogamy). However, Bauhinia forficata did not present fruit formation in the isolated floral buds, indicating that in addition to the inability to perform autogamy, the species also presents some mechanism of genetic incompatibility that prevents reproduction by geitonogamy, and consequently pollination between individuals with a high degree of kinship, thereby reducing the inbreeding of the populations.

Inability to perform geitonogamy is especially important to ensure genetic variability in species that have vegetative propagation such as Bauhinia forficata, which emits shoots from the root, and therefore forms genetically homogenous groups or with a high degree of kinship. Moreover, if confirmed, this would represent an important ecological adaptive mechanism of the species and would consolidate it as a key species for biodiversity reintroduction processes, being necessary with further studies on the sexual system(s) of the species with the objective of testing the above mentioned hypothesis.

\section{CONCLUSION}

The species presented an inability to perform autogamy. The pollen viability of Bauhinia forficata was considered high, independent of the dye used for the cytochemical tests.

The dyes used were able to clearly distinguish the viable pollen grains from the unviable ones, with the exception of the Safranin dye, with its use not being recommended to determine pollen viability for this species.

Due to the ability to detect enzymatic activity involved in the respiration process, the use of TTC dye to determine pollen viability of the species is recommended, however, it was noted that Methyl Red and Basic Fuchsin dyes also presented satisfactory results.

Optimization of strategies to encourage cross-breeding is evident, even with the existence of hermaphrodite flowers in Bauhinia forficata, such as: characteristics related to attraction of visitors, supply of floral resources, large amounts of pollen, high pollen viability and the 
inability to perform autogamy, show that the species developed mechanisms to control and induce genetic flow, and thereby increase pollination quality.

\section{ACKNOWLEDGEMENTS}

FAPERGS for granting the scholarship to the first author of this article and to Mr. Oswaldo Carlesso and his wife for making the study area available.

\section{SUBMISSION STATUS}

Received: 11 june, 2017

Accepted: 26 july, 2017

\section{CORRESPONDENCE TO}

\section{Luana Camila Capitani}

Departamento de Ciências Florestais, Centro de Ciências Rurais, Universidade Federal de Santa Maria - UFSM, Rua João Costa, 490, Bairro Camobi, CEP 97105-200, Santa Maria, RS, Brasil e-mail: lumilacapitan@gmail.com

\section{FINANCIAL SUPPORT}

Fundação de Amparo à Pesquisa do Estado do Rio Grande do Sul - FAPERGS.

\section{REFERENCES}

Agostini K, Lopes AV, Machado IC. Recursos florais. In: Rech AR, Agostini K, Oliveira PE, Machado IC, editors. Biologia da polinização. Rio de Janeiro: Projeto Cultural; 2014. $517 \mathrm{p}$.

Aguiar WM, Gaglianone MC. Comportamento de abelhas visitantes florais de Lechytis lurida (Lechytidaceae) no norte do estado do Rio de Janeiro. Revista Brasileira de Entomologia 2008; 52(2):277-282. http://dx.doi.org/10.1590/ S0085-56262008000200007.

Akoroda MD. Floral biology in relation to hand pollination of white yam. Euphytica 1983; 32(3): 831-838. http:// dx.doi.org/10.1007/BF00042164.

Allen AM, Hiscock SJ. Evolution and phylogeny of selfincompatibility systems in angiosperms. In: Franklin-Tong VE, editor. Self-incompability in flower plants: evolution, diversity, and mechanisms. Berlin: Springer; 2008. $314 \mathrm{p}$. http://dx.doi.org/10.1007/978-3-540-68486-2_4.

Arenas-de-Souza MD, Silveira GF, Silva MSA, Karsburg IV. Estimativa da viabilidade polínica em indivíduos de
Tabebuia impetiginosa e Tabebuia crysotricha (Mart. ex. DC.) Standl. (Bignoniaceae) através de métodos citoquímicos. Enciclopédia da Biosfera 2014; 10(18): 3864-3871.

Avila AL, Araujo MM, Longhi SJ, Gasparin E. Caracterização da vegetação e espécies para recuperação da mata ciliar, Ijuí, RS. Ciência Florestal 2011; 21(2): 251-260. http:// dx.doi.org/10.5902/198050983229.

Bolat I, Pirlak L. An Investigation on pollen viability, germination and tube growt in some stone fruits. Turkish Journal of Agriculture and Forestry 1999; 23: 383-388.

Cargnelutti A, Storck L, Lúcio ADC, Lopes SJ. Testes não-paramétricos para pesquisas agrícolas. Santa Maria: Departamento de Fitotecnia, UFSM; 2001. 97 p.

Davide LMC, Pereira RC, Abreu GB, Souza JC, Von Pinho EVR. Viabilidade de pólen de milho em diferentes períodos de armazenamento em baixa temperatura. Revista Brasileira de Milho e Sorgo 2009; 8(2): 199. http://dx.doi. org/10.18512/1980-6477/rbms.v8n2p199-206.

Engel IC, Ferreira RA, Cechinel-Filho V, Meyre-Silva C. Controle de qualidade de drogas vegetais a base de Bauhinia forficata Link (Fabaceae). Revista Brasileira de Farmacognosia 2008; 18(2): 258-264. http://dx.doi. org/10.1590/S0102-695X2008000200021.

Frankham R. Challenges and opportunities of genetic approaches to biological conservation. Biological Conservation 2010; 143(9): 1919-1927. http://dx.doi. org/10.1016/j.biocon.2010.05.011.

Hister CAL, Tedesco SB. Estimativa da viabilidade polínica de araçazeiro (Psidium cattleianum Sabine) através de distintos métodos de coloração. Revista Brasileira de Plantas Medicinais 2016; 18(1): 135-141. http://dx.doi. org/10.1590/1983-084X/15_081.

Lin H, Gomez I, Meredith JC. Pollenkitt wetting mechanism enables specie-specific tunable pollen adhesion. Langmuir 2013; 29(9): 3012-3023. http://dx.doi.org/10.1021/ la305144z. PMid:23402563.

Longhi SJ, Brun EJ, Oliveira DM, Fialho LEB, Wojciechowski JC, Vaccaro S. Banco de sementes do solo em três fases sucessionais de uma Floresta Estacional Decidual em Santa Tereza, RS. Ciência Florestal 2005; 15(4): 359-370. http://dx.doi.org/10.5902/198050981873.

Lunau K. Stamens and mimic stamens as components of floral colour patterns. Botanische Jahrbücher für Systematik, Pflanzengeschichte und Pflanzengeographie 2006; 127(1): 13-41. http://dx.doi.org/10.1127/0006-8152/2006/0127-0013.

Maluf JRT. Nova classificação climática do Estado do Rio Grande do Sul. Revista Brasileira de Agrometeorologia 2000; 8(1): 141-150.

Marangon LC, Soares JJ, Feliciano ALP, Brandão CFLS. Regeneração natural em um fragmento de Floresta Estacional Semidecidual em Viçosa, Minas Gerais. Revista Árvore 2008; 32(1): 183-191. http://dx.doi.org/10.1590/ S0100-67622008000100020. 
Marques GS, Rolim LA, Alves LDS, Silva CCAR, Soares LAL, Rolim-Neto PJ. Estado da arte de Bauhinia forficata Link (Fabaceae) como alternativa terapêutica para o tratamento de Diabetes mellitus. Revista de Ciências Farmacêuticas Básica e Aplicada 2013; 34(3): 313-320.

Mendes FN, Rêgo MMC, d’Albuquerque PMC. Fenologia e biologia reprodutiva de duas espécies de Byrsonia Rich. (Malpighiaceae) em área de Cerrado no Nordeste do Brasil. Biota Neotropica 2011; 11(4): 103-115. http:// dx.doi.org/10.1590/S1676-06032011000400011.

Moraes AP, Almeida VP. Levantamento florístico de uma trilha em um fragmento florestal urbano do Parque Zoológico Municipal Quinzinho de Barros, Sorocaba (SP). Revista Eletrônica de Biologia 2009; 2(1): 51-65.

Munhoz M, Pinto-da-Luz CF, Meissner PE Fo, Barth OM, Reinert F. Viabilidade polínica de Carica papaya L.: uma comparação metodológica. Revista Brasileira de Botanica. Brazilian Journal of Botany 2008; 31(2): 209-214. http:// dx.doi.org/10.1590/S0100-84042008000200003.

Nascimento LS, Benevenuti AS, Leite DM, Silva DD, Moura EA, Miranda D et al. Estimativa da viabilidade polínica e índice meiótico de Delonix regia. Estudos 2014; 41: 83-88.

Nicodemo MLF, Porfirio-da-Silva V, Santos PM, Vinholis MMB, Freitas AR, Caputti G et al. Desenvolvimento inicial de espécies florestais em sistema silvipastoril na região sudeste. Colombo: Pesquisa Florestal Brasileira; 2009. p. 89-92. (Nota Técnica; no. 60).

Oliveira PE, Maruyama PK. Sistemas reprodutivos. In: Rech AR, Agostini K, Oliveira PE, Machado IC, editors. Biologia da polinização. Rio de Janeiro: Projeto Cultural; 2014. 517 p.

Paulino HF No. Floral biology and breeding system of Bauhinia forficata (Leguminosae: Caesalpinioideae), a moth-pollinated tree in southeastern Brazil. Brazilian Journal of Botany 2013; 36(1): 55-64. http://dx.doi. org/10.1007/s40415-013-0011-8.

Pezzopane JEM, Reis GG, Reis MGF, Oliveira SN No, Higuchi P. Radiação luminosa e fotossíntese em quatro espécies lenhosas no interior de um fragmento de Floresta Secundária Semidecidual. Floresta e Ambiente 2003; 10(1): 48-57.
Pio LAS, Ramos JD, Pasqual M, Junqueira KP, Santos FC, Rufini JCM. Viabilidade do pólen de laranjas doces em diferentes condições de armazenamento. Ciência e Agrotecnologia 2007; 31(1): 147-153. http://dx.doi. org/10.1590/S1413-70542007000100022.

Rech AR, Agostini K, Oliveira PE, Machado IC. Biologia da polinização. Rio de Janeiro: Projeto Cultural; 2014. 517 p.

Santos OD No, Karsburg IV, Yoshitome MY. Viabilidade e germinabilidade polínica de populações de Jurubeba (Solanum paniculatum L.). Revista de Ciências AgroAmbientais 2006; 4(1): 67-74.

Santos-e-Silva F A. Assistat: assistência estatística. Campina Grande: UFCG; 2015.

Silva KL, Cechinel V Fo. Plantas do gênero Bauhinia: composição química e potencial farmacológico. Química Nova 2002; 25(3): 449-454. http://dx.doi.org/10.1590/ S0100-40422002000300018.

Souza MM, Pereira TNS, Martins ER. Microsporogênese e microgametogênese associadas ao tamanho do botão floral e da antera e viabilidade polínica em maracujazeiroamarelo. Ciência Agrotécnica 2002; 26: 1209-1217.

Valério AF, Watzlawick LF, Saueressing D, Puton V, Pimentel A. Análise da Composição Florística e da Estrutura Horizontal de uma Floresta Ombrófila Mista Montana, Município de Irati, PR- Brasil. Revista Acadêmica Ciências Agrárias e Ambientais 2008; 7(3): 299-304.

Vida AD, Sores TL, Oliveira EJ, Jesus ON, Souza FVD, Cerqueira TT et al. Germinação in vitro e viabilidade polínica em passifloras silvestres. Brasília: EMBRAPA Mandioca e Fruticultura; 2011.

Westerkamp C. Flores e abelhas na disputa. Ciência Hoje 2004; 34: 66-68.

Willmer P. Pollination and floral ecology. New Jersey: Princeton University Press; 2011. http://dx.doi. org/10.1515/9781400838943.

Zanella CM, Janke A, Palma-Silva C, Kaltchuk-Santos E, Pinheiro FG, Paggi GM et al. Genetics, evolution and conservation of Bromeliaceae. Genetics and Molecular Biology 2012;35(4, Suppl 1): 1020-1026. http://dx.doi. org/10.1590/S1415-47572012000600017. PMid:23412953. 